\title{
BIOCIDE BASALT COMPOSITIONS
}

\author{
V.M. Shevchenko, N.A. Guts \\ National Technical University of Ukraine "KPI named Igor Sikorsky", \\ 03056, Kyiv, Peremogyav., 37, (+38044)236-97-74, e-mail: sec@xtf.kpi.ua
}

Materials that contain cellulose fibers as the most common natural carbohydrate are known to be affected by different kinds of molds and microorganisms. 700 bacteria of actinomycete, fungus use cellulose as a source of carbohydrate. These microorganisms have a specific gem - cellulase, which is responsible for a complex biochemical process-destruction of cellulose.

The problem of getting biocide materials that are not affected by different molds and microorganisms is faced by a number of fields of domestic economy. This includes various kinds of package materials used in food, medical, cosmetical, electro-technical, and other industries.

The work demonstrates some possibilities of getting biocide materials based on basalt fibers including cellulose and its ethers processed with solutions of bactericide drugs and define bactericide activity regarding to disease-causing organisms: Staph. aureus, F. Coli, and derivatives of nitrofuran range are used as bactericide reagents.

Appliance of clay minerals of the montmorillonite type in the composition with basalt fibers is proved to get materials that are characterized with high biocide properties and excellent service characteristics. Thus, appliance of basalt fibers in this direction has a very positive perspective.

This paper describes a methodology of producing a strong thin paper-like biocide material based on non-organic basalt fibers, which can be used in many industries of domestic economy.

Keywords: cellulose fibers, natural carbohydrate, biocide materials, molds, microorganisms, clay minerals, basalt fibers, biocide properties, domestic economy.

\section{Introduction}

The problem of getting biocide materials that are not affected by different molds and microorganisms is faced by a number of fields of domestic economy. This includes various kinds of package materials used in food, medical, cosmetical, electro-technical, and other industries. Getting of biocide paper that can stand against bacterias (bacterial), molds (fungicidal), and insects is the problem the mankind has been tackling for a very long time [1].

Biostability of cellulose fibers is being searched and learnt even nowadays. There are several ways of solving this problem: mechanical, fungicidal, etc. [2] Biostability of the materials can be increased by modifying the chemical nature of cellulose. [2] Obviously, it's easier and less expensive to use non-organic fibers in compositions, in particular - basaltic. These fibers (of unlimited fund) are get by stretching under high temperatures with air steam by frictional forces between it and the fiber, which is moving with variable speed. At the same time, fibers are not only stretching, but also are separated, divided. Materials that is being created, has durability of $80 \%$ of the initial one, in distinguish to other natural fibers that are got by the same technology, but with $50 \%$ of the initial durability. 
Basaltic fibers are high-temperature resistant materials, with low chemical activity, which is very important - they do not conduce to spreading of different molds and microorganisms, are not affected by mildew, bacterias, and other pests, rodents, beetles, mosquitoes, etc.

\section{Experimental part}

Getting of carton-like materials basing on basalt fibers (BAS) like tiles, felt, scale, etc is not a problem. Such materials do not contain binders in their composition content, but have evenly intertwined basalt fibers. They have low durability, in practice after vacuuming (drying) they can hardly be taken off the net, as basalt fibers do not have paper-creating properties (not fibrilized, no hydrogen bonds), inter-fiber relations are purely mechanical. That is why for getting a more durable thin paper-like material, applying of bonding substances is critical. Keeping this in mind, depending on the usage conditions and requirements to the ready-to-use product, different binding materials can be applied. The most popular and handy binding material is cellulose (if further used under $120-130^{\circ} \mathrm{C}$ ).

Cellulose (CEL) and basalt fibers have electro-kinetic potential which is equal by sign and opposite by value, and which rise on the boundary of phase separation (solid-fiber-solution). Reloading of the surface of one of the contacting fiber is learnt to give a possibility to get a composition material that consists of oppositely charged particles (reloading of the surface of cellulose fibers goes under

$\mathrm{pH}=3.7-3.8$, but basalt fiber is recharged under $\mathrm{pH}=4.9-5.1$ ), material durability and its biostability is significantly increased [3] Thus, for example, durability of materials with 20-25\% of basalt fiber in composition with cellulose ones during recharge of the cellulose part of fibers is increased more than $24 \%$.

Recharge of cellulose fibers is possible without separation of fiber, using sulfate of aluminium and without changing the potential of basalt fibers (without separating the components). Consequently, mutual coagulation of oppositely charged fibers is increased, properties of materials are improved [4].

Researches performed earlier confirmed that in order to get thin, flexible, and heatresistant material, which stops distribution and development of microorganisms, argillaceous minerals can applied [5]. Bentonite clays are known to be associates of clay minerals with prevalence of montmorillonite (MOT) in them. Mineral content of such clays is high-disperse formations that mainly consist of fractions of less than $0,001 \mathrm{~mm}$.

Affected by water, montmorillonite transfers from elastically brittle condition to the flexible condition because of bound and capillary water. Contact of clays and water provokes an active swelling process. For the sake of research, rock-forming fraction of bentonite clay is selected by soaking in distilled water and pouring out of the top 10sm layer after 24-hour settling.

Pyzhev bentonite of Chercassy deposit was applied in the procedure, as it contains sodium oxide due to which it becomes more active because of intensive hydration and increased stability of the system.

There was a research on possibility of getting and appliance of thin paper-like material based on basalt fiber in compositions with recharged cellulose sulphite fiber (SFI) and its ether (carboximetilcellulose, KMC). Compositions were injected with montmorillonite, a clay mineral. Sorbic acid was used as a fungicidal-active material, which was applied from water suspension with binding material of carboximetilcellulose. Because sorbic acid contains rough disperse particles (up to $100 \mathrm{mkm}$ ), to increase sedimentary stability, it was additionally fragmented in the ball mill to get particles of a middle size $(15-20 \mathrm{mkm})$. This was done to ensure qualitative coverage and significant fungicidal properties of the material [6]. 
The obtained material was processed by 5\%-solution of carboxymethylcellulose. Bactericide activity was researched regarding to pathogenic microorganisms: Staph.aureus and F.coli. Derivatives of nitrofuran and triazine series (furalhyn, hexacid, ethonium, vazin - they depress growth of pathogen bacteria) were used as bactericide reagents. Table 1.

Results of the researches of antibacterial properties of the materials are represented in

From Table 1, it's obvious that the best variant of the composition, which effectively depresses growth of microorganisms, contains basalt $(50 \%)$ and cellulose $(50 \%)$ fibers, sorbic acid $(50 \%)$ and hexacid, $15 \%$ of montmorillonite, a bacterial reagent. Obtained modified materials that are part of basalt and cellulose fibers, and up to $15 \%$ of bentonite clay montmorillonite, were tested against durability and filtering ability in accordance with the methodics [4].

It is proved that a characteristic feature of clay suspensions is their low stability associated with the extremely developed phase interface by the presence of an excess of surface energy that facilitates the aggregation of the particles of the dispersed phase and the coagulation of the system.

Improving the properties of clay suspensions can make them more stable by treating them with surface active water soluble substances of synthetic or natural type. The main one is to increase or develop the swelling process, which is due to the peculiarities of the wall structure of the montmorillonite lattice. The result of the manifestation are hydrophilic properties of the system [7]. The use of surface active substances helps to change the molecular nature of the surface and makes it possible to obtain systems with a new features.

Table 1. Antibacterial properties of the materials

\begin{tabular}{|c|c|c|}
\hline \multirow{2}{*}{ Composite materials } & \multicolumn{2}{|c|}{ Diameter of the microorganism oppression area, mm } \\
\hline $\begin{array}{c}50 \% \text { SFI }+50 \% \text { bas }+ \\
15 \% \text { MOT }+ \text { furalhyn }\end{array}$ & Staph.aureus & 18 \\
\cline { 2 - 3 } & 32 & 48 \\
\hline $\begin{array}{c}50 \% \text { SFI }+50 \% \text { bas }+ \\
15 \% \text { MOT }+ \\
\text { furalhyn }+ \text { sorbic acid }\end{array}$ & 30 & 24 \\
\hline $\begin{array}{c}50 \% \text { KMC }+50 \% \text { bas }+ \\
15 \% \text { MOT }+ \text { hexacid }\end{array}$ & 62 & 42 \\
\hline $\begin{array}{c}50 \% \text { KMC }+50 \% \text { bas }+ \\
15 \% M O T+ \\
\text { hexacid }+ \text { sorbic acid }\end{array}$ & & \\
\hline $\begin{array}{c}50 \% \text { SFI }+50 \% \text { bas }+ \\
15 \% M O T+\text { vazin }\end{array}$ & 46 & 44 \\
\hline $\begin{array}{c}50 \% \text { SFI }+50 \% \text { bas }+ \\
15 \% M O T+\text { ethonium }\end{array}$ & 44 & 42 \\
\hline
\end{tabular}


The effect of polar organic compounds during their exchange adsorption on the surface of clay particles was studied. The behavior of sodium humates of carbonate alkaline reagents $(\mathrm{SH})$ and sodium salts of resin acids of SSRA in relation to a representative of bentonite clays, montmorillonite.

Suspensions of Piezhevsky montmorillonite treated with alkali-reagent proved that $1 \%$ additive is sufficient for research it. Clay suspension under these conditions has acquired high stability and thixotropic properties. The system did not change the structural-mechanical type. There appeared greater rapid elastic deformations, which can be explained by the presence of developed protective shells around solid particles of dispersed phase.

The treatment of montmorillonite particles with sodium salts of resin acids of SSRA showed that $4 \%$ of solutions for this purpose are sufficient to obtain a strong and stable suspension in which conditions are created for the formation of coagulation structures. Significant changes in the surface properties of bentonite clays are achieved by the exchange adsorption of polar organic compounds. In this case, the surface of clay particles is completely or partially a screened polar functional group.

Table 2 demonstrates that appliance of clay minerals with high ion-exchange capacity leads to peptization of particles, their stabilization, and increase of forming the structure. This reflects on basic durability characteristics of the materials. Thus, decrease of binding material in the composition does not mitigate the main parameters of durability and filtering capacity.

Basalt fibers are known [1] to be the great protection from external impact of different fungus, microorganisms, so the authors suggested applying them in compositions for producing package materials (specifically for food designated for long-term storing). The $\mathrm{pH}$ level of environment is known to significantly influence the degree of infecting of plant fibers by molds.

Table 2. Characteristics of materials, containing basalt and cellulos fibers, montmorillonite (15\% by weight of fibers), sodium humate (1\% solution of alkaly reagents) and sodium salts of resin acids ( $4 \%$ solution)

\begin{tabular}{|l|c|c|c|c|}
\hline \multicolumn{5}{|c|}{ Properties of the composition } \\
\hline Properties & $\begin{array}{r}50 \% \mathrm{Cel} \\
+50 \% \mathrm{Bas}\end{array}$ & $\begin{array}{r}50 \% \mathrm{Cel}+50 \% \\
\text { Bas }+15 \% \mathrm{MOT}\end{array}$ & $\begin{array}{c}\text { Bas+ } 15 \% \mathrm{MOT}+ \\
10 \% \mathrm{SH}\end{array}$ & $\begin{array}{r}20 \% \mathrm{Cel}+ \\
80 \% \mathrm{Bas}+ \\
15 \% \mathrm{MOT}+ \\
10 \% \mathrm{SSRA}\end{array}$ \\
\hline Compositions & 416 & 640 & 960 & 980 \\
\hline Fracture, ч.д.П. & 920 & 1220 & 1410 & 1440 \\
\hline Breaking length, m & 18 & 20 & 24 & 26 \\
\hline Air resistance, мм.water & 56 & 64 & 68 & 70 \\
\hline $\begin{array}{l}\text { Capillary sorption, } \\
\text { mm/min }\end{array}$ & & & & \\
\hline
\end{tabular}

As a rule, the optimal value of $\mathrm{pH}$ of nutritious environments for the majority of molds are below 7, though the area of affection varies among fungus. Perfect conditions for formation 
and growth of cellulose are mainly created in acid environment, and only Stachybotrus atra's optimal value is deviated to alkalinity - $\mathrm{pH}=7,5$. It's interesting that increasing of alkalinity, say up to 8 , and its decreasing down to 5,5 - this fungus stops producing cellulose. This can be the reason why the degree of coverage by this fungus is less than by fungus of other kinds. In general, our investigations were held in acid environment ( $\mathrm{pH} 4,9-5,2)$.

The easiest method of research of biostability is the visual one, which involves wetting samples, infecting them with fungus of a particular kind, and placing them in a dark place [8]. The main requirement as for the research methods was that the investigations should have been held in tough conditions for materials and favorable conditions for development of microorganisms.

To be the most objective, stability of the materials against the fungus was tested with three methodics: in liquid environment of Van-Iterson, on the surface of non-alkali ahar (environment of Chapek) and in wet cell with relative humidity of $98 \%$. Seeding was estimated by 10 -degree system, where 10 is the highest degree of overgrowth. The results of the investigation of materials destroy under impact of fungus are represented in Table 3.

Table3. Biostability of materials of different compositions that contain basalt, cellulose fiber, montmorillonite (MOT) in the liquid medium of Van-Interson (1), on the surface of non-alkali ahar - Chapek's environment (2) and in the moist chamber (3)

\begin{tabular}{|c|c|c|c|c|c|c|c|c|c|c|c|c|}
\hline \multicolumn{13}{|c|}{ Phases } \\
\hline \multirow{2}{*}{ Fungi types } & \multicolumn{4}{|c|}{ Liquid phase (I) } & \multicolumn{4}{|c|}{ Solid surface (II) } & \multicolumn{4}{|c|}{ Moist chamber (III) } \\
\hline & $\mathbf{a}$ & b & c & d & $\mathbf{a}$ & b & c & d & a & b & c & d \\
\hline $\begin{array}{l}\text { Chaktomium } \\
\text { glohosum }\end{array}$ & 5 & 3 & 2 & 2 & 6 & 4 & 2 & 2 & 5 & 3 & 2 & 2 \\
\hline $\begin{array}{l}\text { Paecilomuses } \\
\text { varioti }\end{array}$ & 6 & 4 & 2 & 2 & 5 & 4 & 2 & 2 & 5 & 4 & 2 & 2 \\
\hline Stechybotrus atra & 4 & 3 & 2 & 2 & 4 & 3 & 2 & 3 & 5 & 4 & 2 & 2 \\
\hline Mix of types & 6 & 4 & 2 & 2 & 6 & 4 & 2 & 3 & 6 & 4 & 3 & 2 \\
\hline
\end{tabular}

Compounds:
a) $50 \% \mathrm{Cel}+50 \% \mathrm{Bas}$;
b) $50 \% \mathrm{Cel}+50 \%$ Bas $+15 \% \mathrm{MOT}$ (by weight of fibers);
c) $20 \% \mathrm{Cel}+80 \% \mathrm{Bas}+15 \% \mathrm{MOT}$ (by weight of fibers) $+10 \% \mathrm{SH}$;
d) $20 \% \mathrm{Cel}+80 \% \mathrm{Bas}+15 \% \mathrm{MOT}$ (by weight of fibers) $+10 \%$ SSRA.

Where Cel is Cellulose, Bas is Basalt, MOT is Montmorillonite, SSRA is Sodium salts of resin acids, $\mathrm{SH}$ is sodium humate (alkali reagents). 
Only specific and equal in all cases qualities of the nutrient medium were considered. Seeding was performed with equal amount of homogeneous water suspension of spores. From Table 3, it's obvious that there is no material that could stand against fungus infection, but infecting has different degree.

To unify tests of different compositional materials against biodurability, international electro-technical committee suggested a set of fungus, which will be the indicator of biodurability of the materials. Among them, there are three main "cellulose destroyers" (Stachybotrus atra, Chacktomium glohosum, Paecilomyces variety). All the biostability tests are held under the toughest conditions created for the material under investigation, but the most favorable for development of microorganisms. The methodology of identification is described in [4]. To be more objective. samples of materials were tested by three methods: in the liquid environment of Van-Interson, on the surface of non-alkali ahar (Chapek's environment), and in wet cell with the relative humidity of $98 \%$. Seeding was held weekly during 180 days. Results are represented in the Table 3.

Tests were conducted with "clear" and "infected" fungus, meaning selected from the infected paper.

Method of carrying out the tests consisted of two parts of visual observations and qualitative characteristics. Qualitative analysis of the destroyed paper was help in the following way: a sample of the paper without infection with fungus and in a month after infecting were dried till the constant weight and weighted. The difference in the weight gave the quality of the destroyed material.

These samples were tested against biostability in relation to some "active" fungus and microorganisms and microelements. Methodology of tests is described in the [5]. Covering by the fungus was estimation by 10-degree scale. Maximal coverage was equal the minimal stability against the fungus.

\section{Conclusions:}

1. Almost all materials under investigation more or less were affected and destroyed by fungus.

2. Materials that contain more cellulose are affected by fungus more and faster. Samples which content of cellulose is up to $85 \%$ are affected by 5-6 day, in 12-15 days the material is totally covered with fungus. The materials that contain up to $20 \%$ of cellulose fiber are more stable: fungus appears only in 15-17 days.

3. Increase of basalt fiber in the composition content lead to increase biostability of the materials.

4. Biostability materials and their strength characteristics have been significantly improved by introducing bentonite clay - montmorillonite into the composition with the surface treatment with organic compounds such as sodium humate $(\mathrm{SH})$ and sodium salts of resin acids (SSRA).

5. That's it: pathogenic microorganizms such as Staph. Aureus type and depressed F.coli are proved to be depressed in the best way by the composition of $50 \%$ basalt $+50 \% \mathrm{KMC}$ $+50 \% \mathrm{MOT}+$ hexacid + sorbic acid.

6. The best indicators are got by materials that contain bentonite clay of the montmorillonite kind and little quantity if cellulose fibers $(30 \%)$. 


\section{Literature}

1. Shevchenko V.M., Pidgornyi A.V., Guts N.A. Getting paper-like materials with antibacterial properties basing on basalt and cellulose fibers// Collection of scientific works SWorld. 2012. - Issue №4(44). - P.99-103

2. Nuyksha Y.P. Systematic review of fungus, who live on paper, books, etc. //Botanical Journal.- 1978. - Issue №46(1). - P.70.

3. Shevchenko V.M., Guts N.A., Pidgornyi A.V. Bentonite clays in compositions with basalt fibers//Collection of scientific works SWorld. - 2016. - Issue №1 (42), book 10.- P. 80-83.

4. Shevchenko V.M., Guts N.A., Pidgornyi A.V. Application of disperse minerals while getting biocide materials based on basalt fibers// Collection of scientific works SWorld. - 2015. Issue №3 (40), book 12. - P. 52-55.

5. Shevchenko V.M., Alekseev O.L. The principle of recharging and its influence to properties of paper-like materials// Thesis of the conference "Nano-size systems", 2004, Kyiv, №12, p.170.

6. Shevchenko V.M., Pidgornyi A.V., Guts N.A., Duda T.I. Compositional materials of basalt fibers// Vistnyk of NTU "Kharkiv polytechnical university". Collection of scientific works. Tematical issue "Chemistry, chemical technology and ecology". - Kharkiv: NTU, "KPI". 2010. - №11. - P.164-170.

7. Kruglitskyi N.N. Physics-chemical bases of regulating properties of the disperse of clay minerals. Kyiv, Naukova dumka, 1994.

8. Shevchenko V.M., Guts N.A., Pidgornyi A.V. Adsorption of montmorillonite clays in compositions with basalt fibers// Collection of scientific works SWorld. - 2017. - Issue №6 (46). - P. 57-61.

\section{References}

1. Shevchenko V.M., Pidgornyi A.V., Guts N.A. Getting paper-like materials with antibacterial properties basing on basalt and cellulose fibers. Collection of scientific works SWorld. 2012. 4(44): 99.

2. Nuyksha Y.P. Systematic review of fungus, who live on paper, books, etc. Botanical journal. 1978. 46(1): 70.

3. Shevchenko V.M., Guts N.A., Pidgornyi A.V. Bentonite clays in compositions with basalt fibers. Collection of scientific works SWorld. 2016. Book 10. 1(42): 80.

4. Shevchenko V.M., Guts N.A., Pidgornyi A.V. Application of disperse minerals while getting biocide materials based on basalt fibers. Collection of scientific works SWorld. 2015. Book 12. 3(40): 52.

5. Shevchenko V.M., Alekseev O.L. The principle of recharging and its influence to properties of paper-like materials. In: The conference "Nano-size systems". (Kyiv, 2004). P. 170.

6. Shevchenko V.M., Pidgornyi A.V., Guts N.A., Duda T.I. Compositional materials of basalt fibers. Vistnyk of NTU "Kharkiv polytechnical university". Collection of scientific works. Tematical issue "Chemistry, chemical technology and ecology". N 11. (Kharkiv: NTU, "KPI", 2010). P. 164.

7. Kruglitskyi N.N. Physics-chemical bases of regulating properties of the disperse of clay minerals. (Kyiv: Naukova dumka, 1994).

8. Shevchenko V.M., Guts N.A., Pidgornyi A.V. Adsorption of montmorillonite clays in compositions with basalt fibers. Collection of scientific works SWorld. 2017. 6(46): 57. 


\section{БІОЦИДНІ КОМПОЗИЦІї 3 БАЗАЛЬТОМ}

\section{В.М.Шевченко, Н.А.Гуц}

Національний технічний університет Украйни « Київський політехнічний інститут імені Ігоря Сікорського», 03056, Київ, пр. Перемоги, 37, (+38044)236-97-74, e-mail:

$$
\text { sec@xtf.kpi.ua }
$$

Про те, щуо матеріали, у складі яких містяться найбільш розповсюджені у природі вуглеводи - целюлозні волокна, піддаються впливу різноманітних плісньових грибів та мікроорганізмів відомо давно. 700 бактерій актиномічетів та грибів використовують целюлозу як джерело вуглецю. Ці мікроорганізми містять специфічний фермент целюлазу, щьо відповідає за руйнування цчелюлози.

Проблема одержання біоцидних матеріалів, щзо не підпадають під вплив різного роду плісньових грибів та мікроорганізмів турбує багато напрямків та галузей промислового виробництва. Наприклад, різного типу пакувальні матеріали, щзо використовуються в харчовій, медичній, косметичній, електротехнічній та інших напрямках промислового виробництва.

У роботі продемонстровано деякі можливості одержання біочидних матеріалів на основі базальтових волокон з використанням целюлози та ї̈ ефірів, щэо оброблені розчинами бактерицидних препаратів - похідними нітрофуранового ряду та визначають бактерищидну активність по відношенню до хвороботворних організмів: стафілококу золотистому (Staph. Aureus), кишківної палочки (F. Coli).

Досліджено, щзо використання у композиції з базальтовими волокнами глинистих мінералів типу монтморилонітів дозволяе одержати матеріали, щзо характеризуються високими біочидними властивостями та хорошими службовими характеристиками. Таким чином, використання базальтових волокон у даному напрямку - дуже перспективно.

Ключові слова: целюлозні волокна, природні вуглеводи, біоцидні матеріали, иявілі, мікроорганізми, глинисті мінерали, базальтові волокна, біоцидні властивості, вітчизняна економіка. 


\section{БИОЦИДНЫЕ КОМПОЗИЦИИ С БАЗАЛЬТОМ}

\section{В.М. Шевченко, Н.А. Гуц}

Национальный технический университет Украины «Киевский политехнический институт имени Игоря Сикорского», 03056, Киї, пр.Победы, 37, (+38044)236-97-74, e-mail: sec@xtf.kpi.ua

Материаль, в составе которых содержатся наиболее распространенные в природе углеводы - целлюлозные волокна, подвергаются воздействию различных плесневых грибов и микроорганизмов известно давно. 700 бактерий актиномицетов и грибов используют иеллюлозу как источник углерода. Эти микроорганизмы содержат специфический фермент - иеллюлоза, отвечающий за разрушения цееллюлозы.

Проблема получения биоцидных материалов, не подвергающихся влиянию разного рода плесневых грибов и микроорганизмов беспокоит многие направления и отраслей промышленного производства. Например, различного типа упаковочные материаль, используемые в пищевой, медицинской, косметической, электротехнической и других направлениях промышленного производства.

В работе продемонстрированы некоторые возможности получения биоцидных материалов на основе базальтовых волокон с использованием иеллюлозы и ее эфиров, обработанные растворами бактерицидных препаратов - производных нитрофуранового ряда и определяют бактерицидную активность по отношению $к$ болезнетворным организмам: стафилококка золотистого (Staph. Aureus), кишечной палочки (F. Coli).

Доказано, что использование в композиции с базальтовыми волокнами глинистых минералов типа монтмориллонита позволяет получить материаль, характеризующиеся высокими биоцидными свойствами и хорошими служебными характеристиками. Таким образом, использование базальтовых волокон в данном направлении - очень перспективно.

Ключевые слова: целлюлозные волокна, природные углеводы, биочидные материаль, плесень, микроорганизмы, глинистые минераль, базальтовые волокна, биоцидные свойства, отечественная экономика. 